Article

\title{
Synergistic Co-Digestion of Microalgae and Primary Sludge to Enhance Methane Yield from Temperature-Phased Anaerobic Digestion
}

\author{
Mekdimu Mezemir Damtie ${ }^{1,+} \mathbb{D}$, Jingyeong Shin ${ }^{1, \dagger}{ }^{,}$Hyun Min Jang ${ }^{2}$ and Young Mo Kim ${ }^{1, *}$ \\ 1 Department of Civil and Environmental Engineering, Hanyang University, Seongdong-gu, Seoul 04763, \\ Korea; mekdimumez@gmail.com (M.M.D.); koung7159@gmail.com (J.S.) \\ 2 Department of Environmental Engineering and Soil Environment Research Center, \\ Jeonbuk National University, Jeonju, Jeollabukdo 54896, Korea; jhm@jbnu.ac.kr \\ * Correspondence: youngmo@hanyang.ac.kr; Tel.: +82-2-2220-0314; Fax: +82-2-2220-0399 \\ + These authors equally contributed to this work.
}

Received: 9 August 2020; Accepted: 31 August 2020; Published: 2 September 2020

\begin{abstract}
A two-stage temperature-phased mesophilic anaerobic digestion assay was carried out to study the interaction between various biological pretreatment conditions and the possible synergistic co-digestion of microalgae and primary sludge. The study of growth kinetics of the biochemical methane potential test revealed that a maximum of $36 \%$ increase in methane yield was observed from co-digestion of a substrate pretreated by thermophilic aerobic conditions $\left(55^{\circ} \mathrm{C}\right.$ and $\mathrm{HRT}=2$ days) and an $8.3 \%$ increase was obtained from the anaerobic pretreated substrate $\left(55^{\circ} \mathrm{C}\right.$ and HRT $=3$ days). Moreover, no synergistic effects on methane yields were observed in co-digesting the substrate pretreated with high temperature $\left(85^{\circ} \mathrm{C}\right)$. The study also identified specific conditions in which interaction between biological pretreatment and co-digestion might substantially reduce methane yield. Careful optimization of operating conditions, both aerobic and anaerobic pretreatment at moderate thermophilic conditions, can be used as a biological pretreatment to enhance methane yield from the co-digestion of microalgae and primary sludge.
\end{abstract}

Keywords: anaerobic digestion; co-digestion; microalgae; primary sludge; biological pretreatment; methane yield

\section{Introduction}

Environmental pollution associated with wastewater treatment plants has become a serious global challenge demanding concerted action [1]. Using microalgae has been one of several efficient techniques for removing phosphorous, nitrogen and toxic metals from partially treated wastewater units [2-4]. Microalgae used for reducing pollutants in wastewater can be consumed during biogas production in anaerobic digestion (AD). Even though its methane yield is quite low due to recalcitrant cell walls and low $\mathrm{C} / \mathrm{N}$ ratios [5], various carbon-rich sources have been co-digested with the microalgae to enhance biogas production. To date, there have been some successful attempts to produce biogas from the co-digestion of microalgae and primary sludge in the anaerobic digester [6-8]. Co-digestion trials have been generally conducted to reduce the time lag of methane yield [9] as well as improve the methane production of mono-digestion by facilitating synergies between substrates via allocating appropriate $\mathrm{C} / \mathrm{N}$ ratios and reducing the risk of methane inhibitors [7].

Among various methods proposed to enhance the performance of anaerobic digestion, pre-treatment has been most widely used to improve biodegradability and the hydrolysis rate [10]. There are many pretreatment technologies, including physical, chemical, biological and hybrid technologies that have been applied to microalgae [11]. Biological pretreatments refer to bio-degradation 
incorporating enzymes and enzymatic cocktails [12] or using different microbial communities (bacteria, fungi, archaea) in direct contact with microalgae to disrupt their cell walls [11]. Among existing biological pretreatment techniques, the use of carbohydrolases has been the most studied and applied to microalgae. However, relatively less attention has been given to the use of thermophilic aerobic or anaerobic digestion as a pretreatment. This microbial aerobic or anaerobic pretreatment technology is a phase separation method (multi-phase fermentation) which generally refers to a process similar to those commonly known as a temperature-phased anaerobic digestion process [13] and two-stage thermal-aerobic and mesophilic anaerobic conditions [14], respectively. In these processes, hydrolysis and the acid formation phase generally run in the first stage (pretreatment), and the methanogenic phase, in the second stage (anaerobic digester).

Because of limited applications and lack of information, biological pretreatment processes for microalgae have been only marginally investigated. Some of the previously carried out studies on different substrates have also reported drops in methane yields and deterioration in efficiency from biological pretreatments during co-digestion [11,15]. There are various complex interactions in the digester linked to the simultaneous application of biological pretreatment and co-digestion. Wang et al. [16] studied improvements in methane yields and the existence of synergistic effects in co-digesting Chlorella sp. with waste activated sludge. Similarly, Solé-Bundó et al. [17] identified a lack of synergy in non-pretreated substrates (a combination of microalgae and wheat straw) which, in turn, showed some negative interferences from the pretreatment-co-digestion relationship. Olsson et al. [18] used a kinetic model study to demonstrate no synergism in the co-digestion of microalgae and sewage sludge in thermophilic conditions. Bohutskyi et al. [9] also studied synergistic co-digestion of algal-bacteria and cellulose using kinetic modeling and showed the possibility of negative synergistic effects. Such disparity in experimental results arises from a lack of full understanding of the processes as well as disparity in selecting appropriate operating parameters.

The objective of this work is, therefore, to study the synergistic effects of co-digestion of primary sludge and microalgae and their interactions with biological pretreatments with an aim to provide a clear strategy to maximize methane yields. Three possible pretreatment scenarios, namely aerobic pretreatment, anaerobic pretreatment, and high-temperature anaerobic pretreatment conditions were considered, and their results were compared with the control (no pretreatment) condition to understand and explore the synergistic impact of co-digestion during methanogenesis. The observed results were then validated using the parameters of a kinetic model. The novelty of this study lies in its simultaneously considering the effect of different kinds of substrates (primary sludge and algae), redox conditions (aerobic and anaerobic), and different operating temperatures. Previous work has only infrequently considered all these factors at once. In addition, the kinetics of possible biochemical methane assays have also been modeled and employed to further elucidate achieving improved methane yield potentials and production rates from each pretreatment method by suggesting precautions to be taken during anaerobic digestion.

\section{Materials and Methods}

\subsection{Preparation and Characterization of Substrate and Inoculum}

Both microalgae and primary sludge were used as feeding substrates for the co-digestion. The physicochemical characteristics of the concentrated raw microalgae and primary sludge were quantified using the analytical methods described in Section 2.4 and results are indicated in Table 1. Detailed information about the collection, storage, preparation, characterization and use of the substrate is described as follows. 
Table 1. Characteristics of the raw micro-algal biomass, raw primary sludge and inoculum.

\begin{tabular}{cccc}
\hline Parameter & Microalgae & Primary Sludge & Inoculum \\
\hline $\mathrm{pH}$ & 7.7 & 6.1 & 7.61 \\
\hline Total solids, TS $(\mathrm{g} / \mathrm{L})$ & $114.3 \pm 0.9>$ & $49.3 \pm 7.2$ & $27.77 \pm 0.8$ \\
\hline Volatile solids, VS $(\mathrm{g} / \mathrm{L})$ & $108.3 \pm 0.2$ & $33.6 \pm 4.8$ & $17.30 \pm 2.1$ \\
\hline Total chemical oxygen demand, tCOD $(\mathrm{g} / \mathrm{L})$ & $103.5 \pm 0.2$ & $87.0 \pm 4.4$ & $14.31 \pm 0.3$ \\
\hline Soluble chemical oxygen demand, sCOD $(\mathrm{g} / \mathrm{L})$ & $5.4 \pm 0.0$ & $11.2 \pm 0.9$ & 4.25 \\
\hline Soluble carbohydrate $(\mathrm{g} / \mathrm{L})$ & $2.1 \pm 0.1$ & $0.8 \pm 0.0$ & - \\
\hline Soluble protein $(\mathrm{g} / \mathrm{L})$ & $1.1 \pm 0.1$ & $2.7 \pm 0.2$ & $2.66 \pm 0.4$ \\
\hline
\end{tabular}

\subsubsection{Algal Biomass Preparation}

A freshwater cultivated Chlorella vulgaris microalgal biomass was obtained from Daesang, Korea. The algal biomass was grown in synthetic media in an industrial reactor free of bacterial contamination using a controller at a temperature of $30^{\circ} \mathrm{C}$ in dark conditions. The growing media was augmented with $8-10 \%$ liquid sugar to speed up the microalgae growth. Reactors were aerated at a flow rate of $1 \mathrm{vvm}$ (volume of air per volume of microalgae per minute) using air spargers and maintaining the same culture conditions. The agitation speed for mixing was $90 \mathrm{rpm}$. The concentration of total solids was $\approx 114.3 \mathrm{~g} / \mathrm{L}$ and the $\mathrm{pH}$ of the media kept between 7.5 and 8.0 during cultivation. These microalgae were physicochemically characterized and stored at $+4{ }^{\circ} \mathrm{C}$ until the start of the pretreatment tests. During the experiment, the raw microalgae were diluted twice with tap water to keep the appropriate range of concentration since a total solid value larger than $100 \mathrm{~g} / \mathrm{L}$ was too high to use in the reactor. All the biological pretreatments were carried out in semi-continuous mode.

\subsubsection{Primary Sludge, Inoculum and the Sampling Plant}

The primary sludge and the inoculums were collected from a wastewater treatment plant located in the southwestern region of Korea (Gwangju, Korea). This full-scale municipal treatment plant is one of Korea's largest wastewater treatment plants with a total treatment capacity of 600,000 tons/day dedicated to treating wastes of poultry farms and domestic sewage from almost $73 \%$ of the total population of the city. This plant uses mainly traditional treatment processes, including primary sedimentation, biological treatment, coagulation, filtration, and tertiary treatment (disinfection). The biological component encompasses a sequential process of anaerobic, anoxic and oxic tanks. More detailed information about this plant can be obtained from [19]. The primary sludge sample was taken directly from the pre-sedimentation section after the gravity thickening stage of the mixed sludge. Then, samples were carried to the laboratory using $1 \mathrm{~L}$ plastic containers. Once the primary sludge was collected, samples were sieved and stored at $+4{ }^{\circ} \mathrm{C}$ before beginning the experiments. The inoculum for microalgae pre-treatment was also obtained from the effluent of a full-scale mesophilic anaerobic digester at the same treatment plant. However, inoculum for the pretreatment of microalgae under aerobic conditions was obtained from the activated sludge effluent from the thickener in the secondary treatment part.

The overall physiochemical composition and characteristics of the micro-algal biomass and the primary sludge are shown in Table 1.

\subsection{Phase One (Thermophilic Pre-Treatment of Microalgae)}

Pretreatment of the microalgae biomass was carried out using a $5 \mathrm{~L}$ reactor $(2.8 \mathrm{~L}$ working volume). The reactors were comprised of a reactor body, heater, heat-regulating jacket, stirrer, and other accessories as shown in Figure 1. The experiments were conducted in such a way that the microalgae feedstock was first loaded into the reactor and the operating temperatures and reaction times were varied based on the study target. The temperature in the reactor was maintained using heating 
tape. The initial $\mathrm{pH}$ before starting the experiment was set to 7 . The substrate in the reactors was mixed using continuous agitation at a stirring speed of $150 \mathrm{rpm}$. Nitrogen was purged once at the start of the operation of the anaerobic reactors. For aerobic reactors, the system was continuously aerated at a flow rate of $10 \mathrm{~L} / \mathrm{min}$ using air spargers. At the start of the experiment, samples were first pretreated biologically under anaerobic thermophilic conditions. During this test, there were two different operating temperatures $\left(55^{\circ} \mathrm{C}\right.$ and $85^{\circ} \mathrm{C}$ ); each run had three different HRTs (namely 3 days, 2 days and 1 day). Then, the $55^{\circ} \mathrm{C}$ assays were repeated under aerobic conditions using the same HRTs ( 3 days, 2 days and 1 day). Each of these thermophilic reactor conditions was operated for over $860 \mathrm{~h}$. Sampling was conducted manually using a syringe two times per day (for HRT 3 days and 2 days), and three times per day (for HRT 1 day). The sampling volumes were $450 \mathrm{~mL}, 700 \mathrm{~mL}$ and $900 \mathrm{~mL}$ for HRTs of 3 days, 2 days and 1 day, respectively. A duplicate value was collected for each situation. Primary sludge was not pretreated, and the original raw sludge was used in the co-digestion experiment for the BMP test. Detailed schematics of the pretreatment plan are shown in Figure 1. Once the microalgae pretreatment was completed, a subsequent BMP test was conducted to study the biomethanization potential. Independent BMP tests were conducted for each test regiment both as mono-digestion and co-digestion schemes.

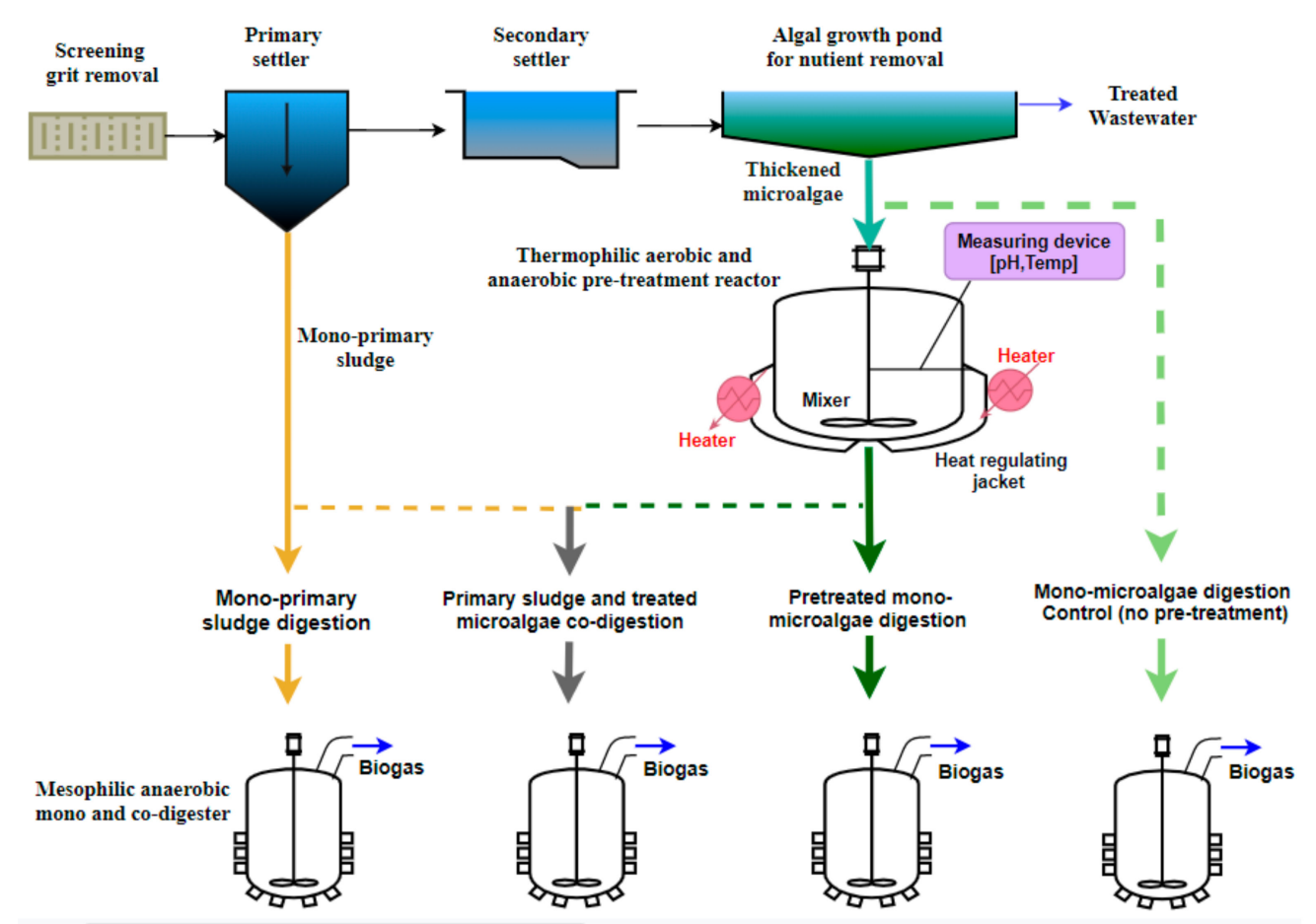

Figure 1. Schematic configuration of substrate source and lab-scale alignments of anaerobic digestion process with and without biological pretreatment.

\subsection{Phase Two (Mesophilic Digestion) BMP Tests}

The above biologically pretreated microalgae were used as a substrate for the BMP tests and digested using a $250 \mathrm{~mL}$ serum bottle ( $150 \mathrm{~mL}$ working volume). Two separate serum bottles were used to duplicate the experiment and improve the accuracy of the daily results. The collected primary sludge was not pretreated, and the original raw sludge was used in the experiment. For mono-digestion, the inoculum and pretreated microalgae substrates were mixed in a ratio of 2:1 (VS basis). Whereas for co-digestion, the volatile solids (VS)-based mix ratio of primary sludge to pretreated microalgae was first set to 9:1. Then, the inoculum was added to the mixed substrate in a VS-based ratio (ISR) of 2:1. Once the feedstock substrate (either primary sludge, microalgae, or a mixture of both) was prepared and loaded into the reactor, the initial $\mathrm{pH}$ was set to 7 . Then, the bottles were plugged with elastic stoppers and aluminum crimp covers. To ensure anaerobic conditions, the headspace 
above the substrate was filled with nitrogen gas. The bottles were then placed into the shaking incubator running at $150 \mathrm{rpm}$ under mesophilic temperature $\left(35^{\circ} \mathrm{C}\right)$ and kept operating for over 35 days until the methane production ceased. The reactor was run under semi-continuous mode. These anaerobic digestion experiments were also carried out using non-pretreated microalgae biomass samples to establish control. Sampling was conducted manually using a syringe twice a day, and the water displacement method was used to measure methane production. Then, biogas yield, methane concentration, vs. and soluble chemical oxygen demand (sCOD) were carefully recorded following each sampling. Results were collected in duplicate and the means and standard errors for all values were calculated. The schematic configuration for the substrate source and lab-scale alignments of the combined digesters are shown in Figure 1.

\subsection{Analytical Procedures and Equipment}

After collecting samples from the digester, analysis of TS, vs. and COD was carried out according to standard methods [20]. Volatile fatty acids (VFA) were measured using a gas chromatograph (GC) (model YL6500 GC, Young Lin Instrument Co., Anyang-si, Korea) and the pH of the samples was determined using a pH meter (Orion star A221, Thermo Fisher Scientific). Temperatures of both the thermophilic and mesophilic digesters were continuously monitored via the inbuilt thermometers. Biogas yield was initially collected using a plastic Tedlar bag. Then, methane yield was measured using the water displacement method. In this technique, a gas collector tank was initially filled with water. Then upon letting some water exit through the bottom of the collector, the tank started replacing the water with the biogas from the plastic bag. The biogas yield was then calculated by assuming the volume of displaced water is equal to the gas collected. Data were collected both from the biological experiment replicates and from the duplicated measurements. In this work, OriginPro 2016 compatible with Windows ${ }^{\circledR} 10$ was used to make all the graphs, and Visual paradigm online diagrams was used to draw the schematics shown in Figure 1.

\subsection{Modeling Kinetics of BMP Assay}

To better understand the dual effect from the co-digestion and the biological pretreatment, the overall BMP kinetics were studied independently. The most common kinetic models used to study the behavior of biogas and methane production from an anaerobic digester include the first-order model, pseudo-parallel 1st-order kinetic model, modified Gompertz model, transference function models, Chen-Hashimoto model, and the Monod type model [21,22]. Among these models, the Modified Gompertz equitation fits well in describing the cumulative BMP results. This is mainly because of its capability to accurately predict the lag-phase in biomass conversion as well as methane production, which is essential for modeling the anaerobic digestion of substrates containing high recalcitrant lignocellulosic biomass that potentially reduces biodegradability $[9,22,23]$. The modified Gompertz equations can be presented as Equation (1):

$$
\mathrm{G}(\mathrm{t})=\mathrm{G}_{0} * \exp \left\{-\exp \left[\frac{\mathrm{R}_{\max } * \mathrm{e}}{\mathrm{G}_{0}}(\lambda-\mathrm{t})+1\right]\right\}
$$

where, $\mathrm{G}(\mathrm{t})$ is methane yield at time $\mathrm{t}\left(\mathrm{mL} / \mathrm{g}\right.$-VS added); $\mathrm{G}_{0}$ is the ultimate methane yield ( $\mathrm{mL} / \mathrm{g}$-VS added); $R_{\max }$ is the maximal methane production rate ( $\mathrm{mL} / \mathrm{g}$-VS added day), $\lambda$ is the duration of lag phase (day); $t$ is the time over the fermentation period (days); and e is the constant equivalent to $\operatorname{Exp}(1)=2.718282$. The following equations, as stated earlier in $[24,25]$, were employed to evaluate the suitability of the models by estimating correlation coefficients $\left(\mathrm{r}^{2}\right)$ (Equation (2)) and the root mean square error (RMSE) (Equation (3)) in Origin software.

$$
\mathrm{r}^{2}=\frac{\sum_{\mathrm{i}=1}^{\mathrm{n}}\left(\mathrm{z}_{\mathrm{i}}-\mathrm{z}\right)\left(\mathrm{w}_{\mathrm{i}}-\mathrm{w}\right)}{\sqrt{\sum_{\mathrm{i}=1}^{\mathrm{n}}\left(\mathrm{z}_{\mathrm{i}}-\mathrm{z}\right)^{2} \sum_{\mathrm{i}=1}^{\mathrm{n}}\left(\mathrm{w}_{\mathrm{i}}-\mathrm{w}\right)^{2}}}
$$




$$
\text { RMSE }=\sqrt{\frac{1}{n} \sum_{i=1}^{n}\left(Z_{i}-w_{i}\right)^{2}}
$$

where $z_{i}$ is the experimental value; $w_{i}$ is the estimated value; and $n$ is the number of data samples.

With this cumulative distribution model, the experimental data from each pretreatment method and substrate type were accurately fitted to the modified Gompertz model (see the $\mathrm{R}^{2}$ value). All the kinetic parameters were estimated for different biological pretreatment conditions. The model outputs were used to study the performance of the co-digestion. Subsequently, the highest magnitude of the potential methane yield (Go), the maximum methane production rate $\left(R_{\max }\right)$, and a short lag-phase $(\lambda)$ were considered to be the most critical factors used to reflect co-digestion performance. These model parameters are also essential toward improving the process economics via reducing digester volume and therefore influencing plant capital investment $[9,26]$.

\section{Results and Discussion}

\subsection{Effects of Co-Digestion on Methane Yield}

Mono-digestion of microalgae has shown a limited impact on methane yield performance owing to their containing recalcitrant substances resistant to biodegradation. Therefore, pretreatment and co-digestion have been one of the most commonly suggested solutions to efficiently extract and enhance the methane yield from the microalgae $[11,18]$. In this section, the potential effect of co-digestion on increasing methane yields in trials of mono-digestion of microalgae between substrates was studied. To this end, a primary sludge substrate was copiously ( $90 \%$ vs.-based) co-digested with the microalgae to enhance the methane yield. A significant increase was observed for all the co-digestion trials even without any pretreatment. To observe the effect of co-digestion, three different samples with different inoculum behavior were compared. These tests were repeats of the same trial, and no changes in the other experimental set-ups were made except for the amount of inoculum. As can be seen in Figure 2a, co-digestion consistently showed a better performance than the mono-digestion of microalgae. The first assay showed a $29 \%$ increase in methane yield; the second and the third assays, $74 \%$, and $39 \%$ increases, respectively. This is mainly because of the synergy created between the individual substrates, which ultimately increased the carbon-to-nitrogen ratio and reduced the risk of potential inhibition from the released ammonia [7]. Enhancing methane production through co-digestion from existing anaerobic digestion without increasing the volume of digesters has also been observed in previous works $[6,7,9]$. However, the yields from mono-digestion of primary sludge in the second and third tests were significantly better than that of co-digestion. This is mainly because both co-digestion and mono-digestion of microalgae entail longer retention times for the digestion of complex biopolymers of algae while the primary sludge retains a higher amount of readily available soluble organic substances for methane production [6]. Such phenomena can also be observed from the double peaks of the average methane yield of mono-digestion of microalgae in Figure $2 \mathrm{~b}-\mathrm{d}$. The first peak represents the methane obtained from the readily available soluble algal biomass, while the second peak refers mainly to the yield obtained from the subsequently available recalcitrant components. A relatively flat curve with only one peak was mainly observed in co-digestion confirming the early breakdown of the microalgae cellular structures due to synergistic effects. A similar trend of methane yield was also observed in a previous study [27]. Hence, it can be deduced from these analyses that co-digestion provided superior performance to microbial degradation of the microalgae biomass. 


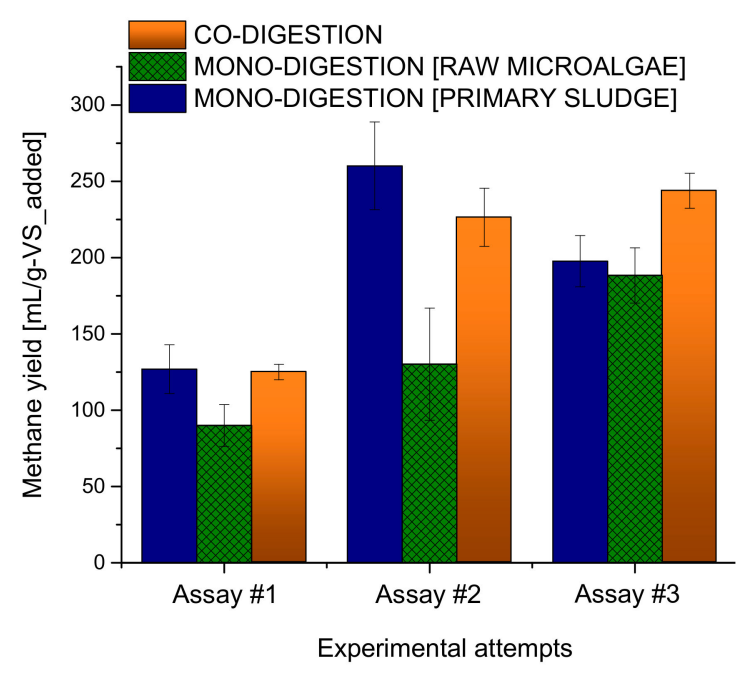

(a)

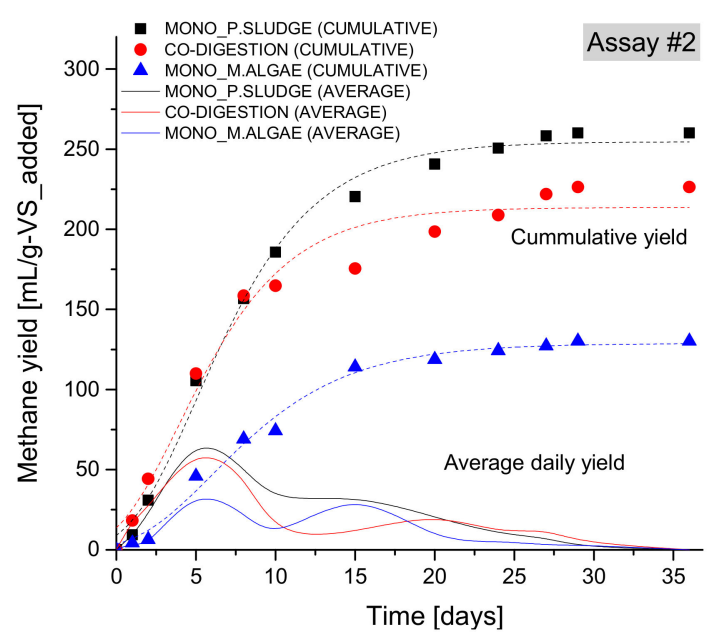

(c)

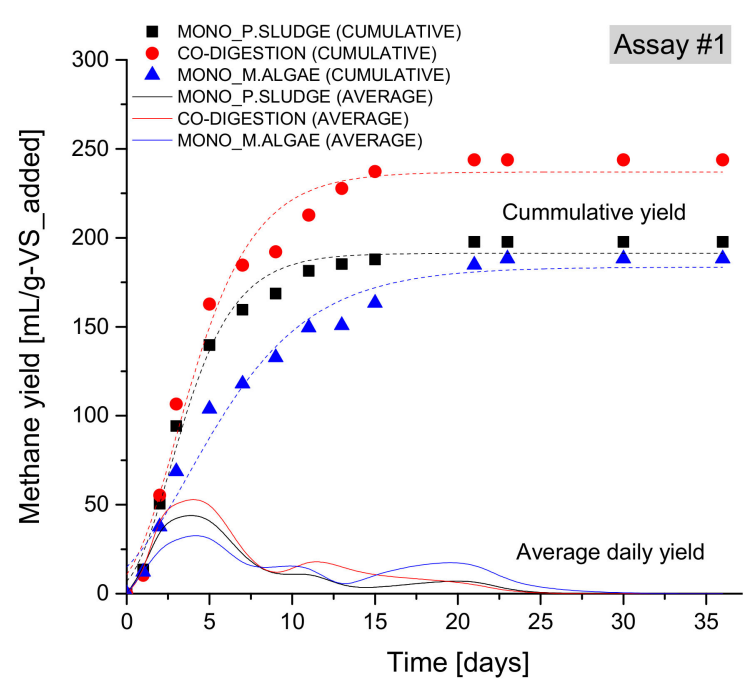

(b)

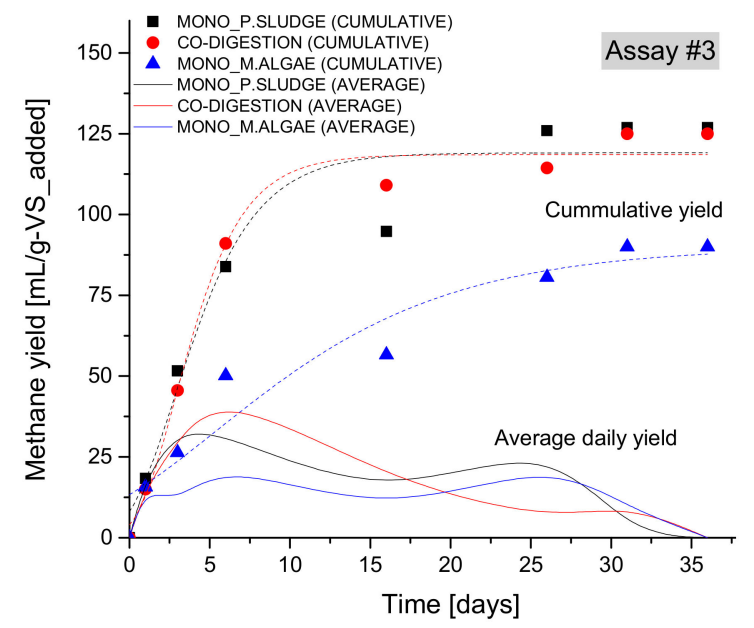

(d)

Figure 2. Methane yield without any biological pretreatment of microalgae: (a) experimental maximum methane yield from different trials with varying inoculums; $(\mathbf{b}-\mathbf{d})$ experimental vs. simulated values of the cumulative yield from three different assays [Experimental condition: Mesophilic AD temperature $=35^{\circ} \mathrm{C}$, Sludge/algae ratio for co-digestion $=9, p H=7.1 \pm 0.2$, ISR $=2$, Working AD volume $=150 \mathrm{~mL}$; Inoculum behavior = Assay\#1: TS = 27.77 g/L, Assay\#2: TS = 36.85 g/L, Assay\#3: TS = $18.73 \mathrm{~g} / \mathrm{L}]$. Note: * The scattered points show measured cumulative values; the broken lines show the simulated trend; and the smooth spline line shows temporal variations of the average daily methane yield. In calculating the the VS_added, the contribution of inoculum was not deducted.

The result from the kinetic model parameters in Table 2 also confirmed similar performance of co-digestion in that the methane potential of the feed stalk $\left(\mathrm{G}_{0}\right)$ and the maximal methane production rate $\left(R_{\max }\right)$ of the co-digestion was consistently higher than mono digestion of microalgae in all assays. A higher cumulative yield of co-digestion can be observed in Figure $2 b-d$. This yield showed up to a $65 \%$ increase in the kinetic model study. In addition, the lag time from the mono-microalgae digestion was improved from 0.34 days, 1.32 days, 2.95 days to 0.33 days, 0.04 days, and 0.52 days, respectively, for all three trials (See Table 2). The next section discusses the impact of co-digestion under three possible biological pretreatment alternatives in terms of enhancing the methane yield of microalgae and offers a possible interpretation of the respective kinetic model parameters. 
Table 2. Kinetic model parameters for different assays (no pretreatment involved).

\begin{tabular}{cccccccccc}
\hline \multirow{2}{*}{$\begin{array}{c}\text { Model * Para } \\
\text { Meters }\end{array}$} & $\begin{array}{c}\text { Mono- } \\
\text { p.sludge }\end{array}$ & $\begin{array}{c}\text { Mono- } \\
\text { m.algae }\end{array}$ & $\begin{array}{c}\text { Ao- } \\
\text { Digestion }\end{array}$ & $\begin{array}{c}\text { Mono- } \\
\text { p.sludge }\end{array}$ & $\begin{array}{c}\text { Mono- } \\
\text { m.algae }\end{array}$ & $\begin{array}{c}\text { Co- } \\
\text { Digestion }\end{array}$ & $\begin{array}{c}\text { Mono- } \\
\text { p.sludge }\end{array}$ & $\begin{array}{c}\text { Mono- } \\
\text { m.algae }\end{array}$ & $\begin{array}{c}\text { Co- } \\
\text { Digestion }\end{array}$ \\
\hline Go & 191.28 & 183.51 & 236.96 & 254.68 & 128.76 & 213.63 & 119.10 & 90.06 & 118.53 \\
$\lambda$ & 0.44 & 0.34 & 0.33 & 0.85 & 1.32 & 0.04 & 0.03 & 2.95 & 0.52 \\
$R_{\max }$ & 32.25 & 16.45 & 33.24 & 22.43 & 9.97 & 20.05 & 15.30 & 3.96 & 18.49 \\
$R^{2}$ & 0.987 & 0.973 & 0.978 & 0.994 & 0.990 & 0.973 & 0.937 & 0.907 & 0.984 \\
\hline
\end{tabular}

Remarks: * Units and descriptions of the model parameters were lag-phase $(\lambda$, days), maximum methane yield (Go, $\mathrm{mL} / \mathrm{g}$-VS_added) and methane production rate $\left(\mathrm{R}_{\max }, \mathrm{mL} / \mathrm{g}\right.$-VS_added/day). ${ }^{* *}$ Initial methane yield data were duplicated. The error band for model parameters lies within $6 \%$.

\subsection{The Dual-Effect of Co-Digestion and Pretreatment}

As previously described, the co-digestion assay demonstrated significantly better methane yields than those by the mono-digestion of the microalgae. However, this was deemed unsatisfactory and uneconomical from a pragmatic viewpoint, as more potential exists to increase the yield by using pretreatment to assist the breakdown of the biopolymers of the microalgae. Therefore, in the following sections, any co-digestion synergistic effect after various pretreatments will be evaluated from the obtained experimental and simulated values.

\subsubsection{Co-Digestion after Aerobic Pretreatment}

Using aerobic digestion as a pretreatment for co-digestion, a maximum methane yield of $308 \mathrm{~mL} / \mathrm{g}$-VS_added was noted at an HRT of 2 days (see Figure 3a). Aerobic pretreatment generally performed better for co-digestion than mono-microalgae digestion and increased the total methane yield by more than $36 \%$ as compared to non-pretreated substrates. This result is much higher than the yield attained under mono-microalgae digestion ( $188 \mathrm{~mL} / \mathrm{g}$-VS_added) and mono-primary sludge (203 mL/g-VS_added) at an HRT of 2 days. The superior methane yield performance of co-digestion might result from the high enzymatic activity of the aerobic microbes [15]. Moreover, the biodegradability of the microalgae when co-digested with the activated primary sludge resulted from the large number and diversity of aerobic microorganisms in the sludge that assisted the initial hydrolysis of the recalcitrant cellulosic cell-wall of the microalgae [14,28]. In addition, the $\mathrm{CO}_{2}$ dissolved in the form of carbonate or bicarbonate might have also been used as a substrate for hydrogenotrophic methanogens [14]. 


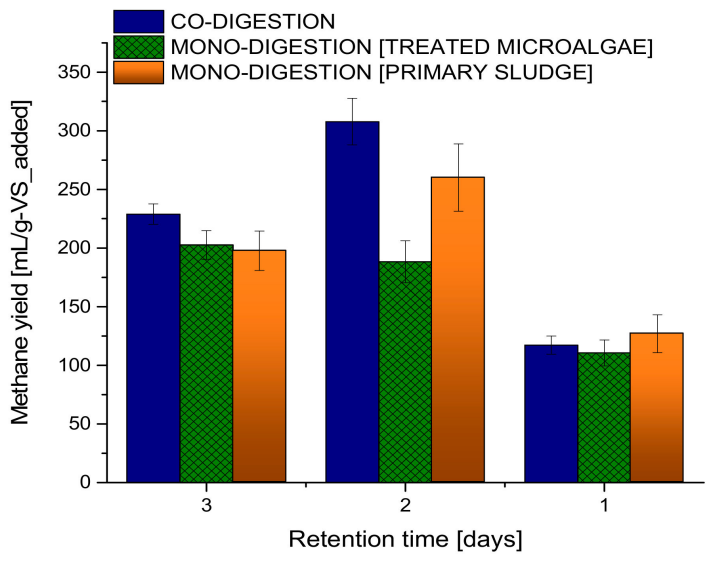

(a)

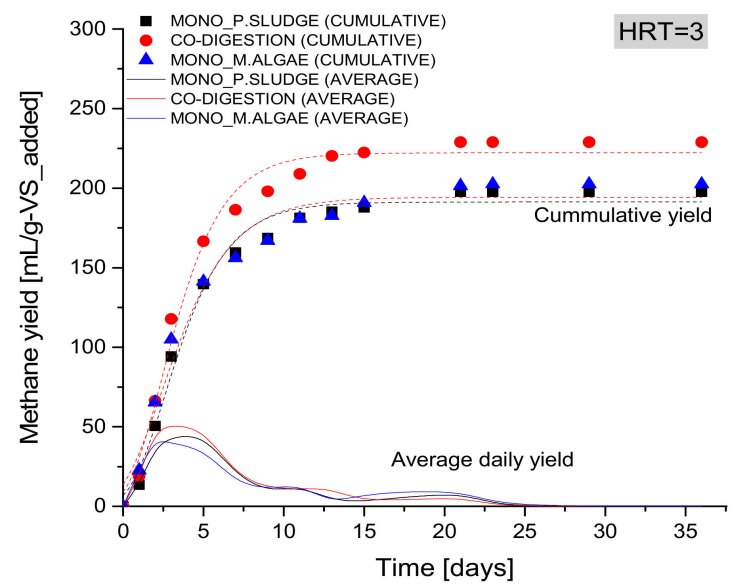

(c)

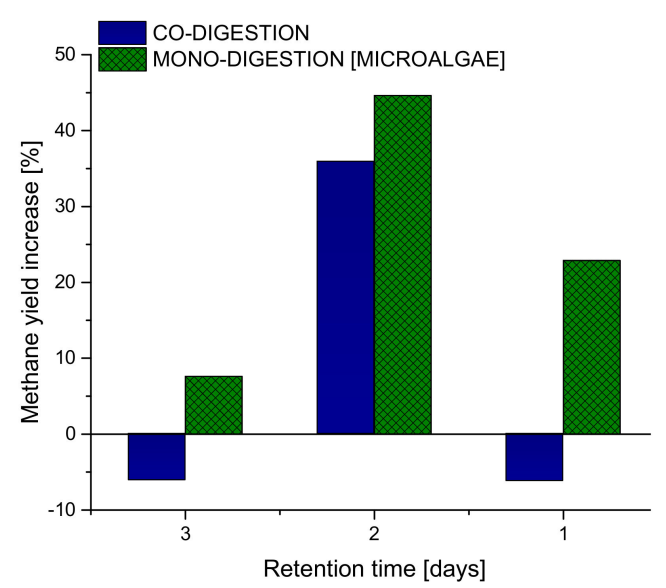

(b)

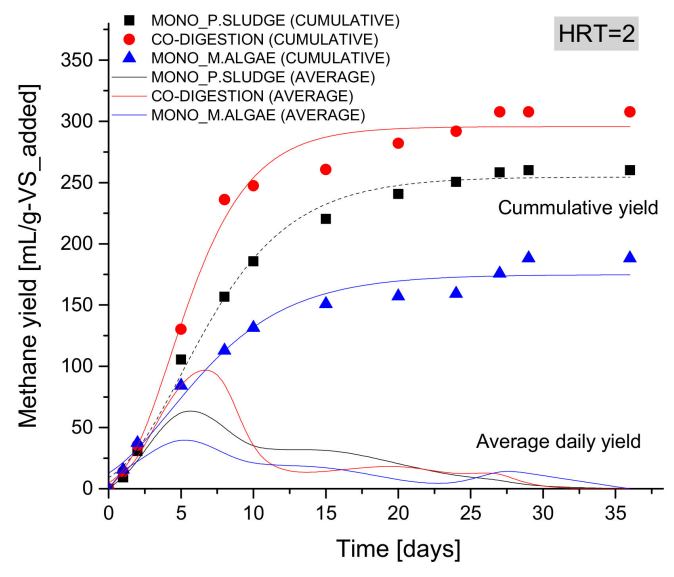

(d)

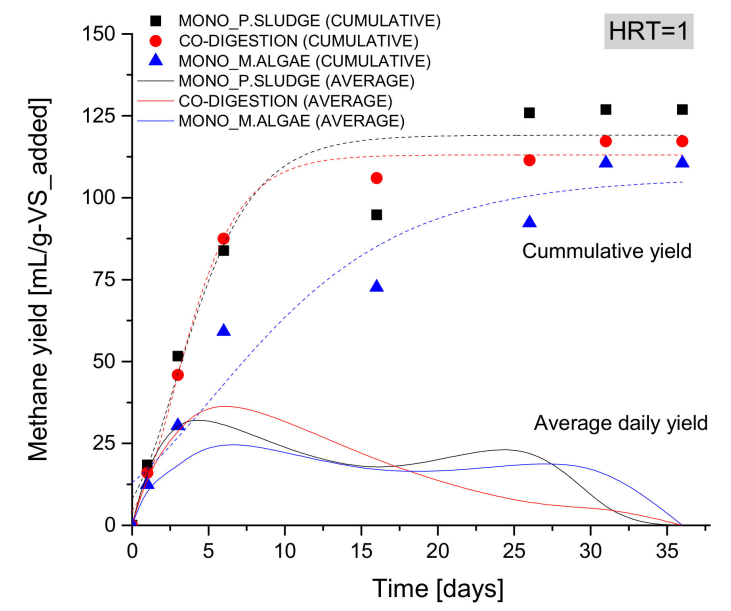

(e)

Figure 3. Methane yield at different HRTs after aerobic biological pretreatment: (a) experimental maximum yield; (b) percentage increase in methane yield as compared to no pretreatment condition; (c-e) experimental vs. simulated values at different HRTs [Experimental condition: Mesophilic AD temperature $=35{ }^{\circ} \mathrm{C}$, Sludge/algae ratio for co-digestion $=9, p H=7.1 \pm 0.2, I S R=2$, Working $A D$ volume $=150 \mathrm{~mL}$. 
However, Figure $3 b$ shows that the relative yield enhancement as compared to the original methane production was larger in the mono-algae digestion (45\%) than in the co-digestion (36\%). Such a greater percentage yield increase in mono-microalgae digestion was attributed to the soluble organic matter being made slowly available as co-digestion was initiated. Interestingly, as compared to the non-pretreated condition, the percentage increase in mono-microalgae digestion at both HRT of 1 day and HRT of 3 days was still noticeably positive while that of co-digestion revealed a reduction of $6.2 \%$ and $4.6 \%$ at an HRT of 3 days and an HRT of 1 day, respectively. This implies that the synergistic impact of co-digestion from the aerobic pretreatment might even have an inhibiting effect if the operating conditions are not properly optimized. This result is in agreement with the model parameter result (e.g., $\mathrm{G}_{0}$ ) of co-digestion in Table 3. The decline in methane yield from a longer HRT $(\mathrm{HRT}=3)$ confirms the microbes (during pretreatment) already started consuming the volatile soluble matter once it was readily available [10]. Also, there may be increased production of $\mathrm{CO}_{2}$ as the soluble organics were used by the aerobic microbes $[11,14]$. However, the decline in methane yield in shorter HRTs might reflect the presence of more aerobic microbial species than anaerobic microbes implying the growth of anaerobic microbes was slower than that of aerobic microbial species.

Table 3. Kinetic model parameters (after aerobic pretreatment).

\begin{tabular}{|c|c|c|c|c|c|c|c|c|c|}
\hline \multirow{2}{*}{$\begin{array}{c}\text { Model Para } \\
\text { Meters }\end{array}$} & \multicolumn{3}{|c|}{ HRT $=3$} & \multicolumn{3}{|c|}{ HRT $=2$} & \multicolumn{3}{|c|}{ HRT $=1$} \\
\hline & $\begin{array}{c}\text { Mono- } \\
\text { p.sludge }\end{array}$ & $\begin{array}{l}\text { Mono- } \\
\text { m.algae }\end{array}$ & $\begin{array}{c}\text { Co- } \\
\text { Digestion }\end{array}$ & $\begin{array}{l}\text { Mono- } \\
\text { p.sludge }\end{array}$ & $\begin{array}{l}\text { Mono- } \\
\text { m.algae }\end{array}$ & $\begin{array}{c}\text { Co- } \\
\text { Digestion }\end{array}$ & $\begin{array}{l}\text { Mono- } \\
\text { p.sludge }\end{array}$ & $\begin{array}{l}\text { Mono- } \\
\text { m.algae }\end{array}$ & $\begin{array}{c}\text { Co- } \\
\text { Digestion }\end{array}$ \\
\hline Go & 191.27 & 194.24 & 222.2 & 254.68 & 174.86 & 295.68 & 119.10 & 106.17 & 113.06 \\
\hline$\lambda$ & 0.44 & 0.06 & 0.34 & 0.85 & 0.17 & 1.26 & 0.03 & 1.84 & 0.41 \\
\hline $\mathrm{R}_{\max }$ & 32.25 & 29.17 & 38.8 & 22.43 & 14.33 & 35.86 & 15.30 & 5.49 & 17.67 \\
\hline $\mathrm{R}^{2}$ & 0.987 & 0.975 & 0.985 & 0.99 & 0.973 & 0.99 & 0.937 & 0.917 & 0.99 \\
\hline
\end{tabular}

Remarks: ${ }^{*}$ Units of $\lambda$ (days), Go (mL/g VS-added), and $R_{\max }=\left(\mathrm{mL} / \mathrm{g}-\mathrm{VS} \_\right.$added/day); error lies within $6 \%$.

The results from the kinetic model parameters in Table 3 also confirmed a similar performance of co-digestion. As compared to co-digestion without pretreatment, co-digestion after aerobic pretreatment enhanced the maximum methane yield by $25 \%\left(\mathrm{G}_{0}=295.7 \mathrm{~mL} / \mathrm{g}\right.$-VS_added $)$ and the methane production rate by $8 \%\left(\mathrm{R}_{\max }=35.8 \mathrm{~mL} / \mathrm{g}\right.$-VS_added/day). However, the maximum methane yield from co-digestion after aerobic pretreatment corresponded to $61 \%$ of the corresponding mono-substrate algae digestion yield. The other interesting finding from the aerobic pretreatment was the hydraulic retention time having the maximum methane yield was obtained at an HRT of 2 days. This reduction in retention time may have resulted from the extended lag period $(\lambda=1.26$ days) observed during the kinetic study of the co-digestion assay. However, the overall time ( $\mathrm{t} \approx 15$ days) required to reach the maximum methane yield was almost the same in all cases, and this lag period may not have a pronounced effect on the final yield. See Figure 3c-e. Similar or even lower methane yield $\left(\mathrm{G}_{0}\right)$ augmentation via co-digestion has been observed for some other lower impact pre-treatment techniques like sonication [10]. Additionally, competitive methane yields were obtained as compared to those costly and less environmentally friendly pretreatment alternatives such as chemical pretreatment supported co-digestion $[17,29,30]$ and thermal pretreatment supported co-digestion [6,7].

\subsubsection{Co-Digestion after Anaerobic Pretreatment}

The highest methane yield in anaerobic pretreatment was $260 \mathrm{~mL} / \mathrm{g}$-VS_added, which was noted at an HRT of 3 days of co-digestion (see Figure 4a). This shows that methane yield was improved by $6.8 \%$ compared to non-pretreated substrate results. In anaerobic pretreatment, selecting the most appropriate hydraulic retention time was also essential, as the methane yield from co-digestion of anaerobic pretreatment was significantly reduced at an HRT of 2 days and an HRT of 1 day (see Figure $4 \mathrm{~b}$ ). Generally, aerobic pretreatment showed more synergistic effects and better methane yield performance $(\sim 18 \%)$ than the anaerobic pretreatment as far as co-digestion is concerned and the retention time in the aerobic condition was also shorter ( 2 days) as compared to an HRT of 3 days in anaerobic pretreatment. However, further detailed economic viability and tradeoffs need to be assessed 
to determine if aerobic pretreatment is actually superior to anaerobic pretreatment because these advantages might add significant costs to the aeration requirements of the aerobic process. On the other hand, in addition to being less costly, anaerobic pretreatment offers other advantages, as it enhances the mono-microalgae digestion by more than $20 \%$ as compared to the aerobic mono-digestion. If one has to use biological pretreatment for mono-microalgae decomposition, the anaerobic pretreatment is relatively a better choice.

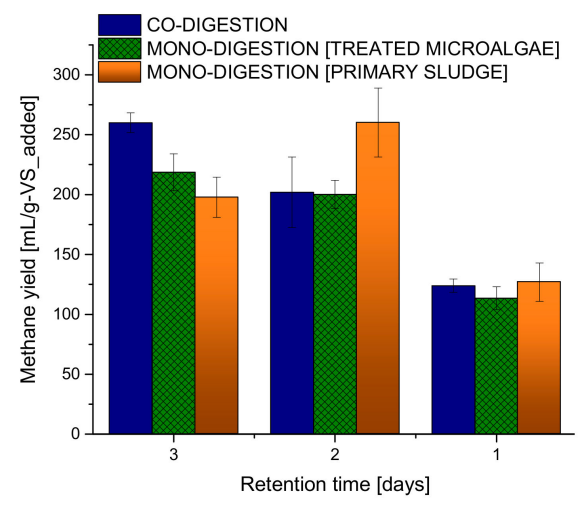

(a)

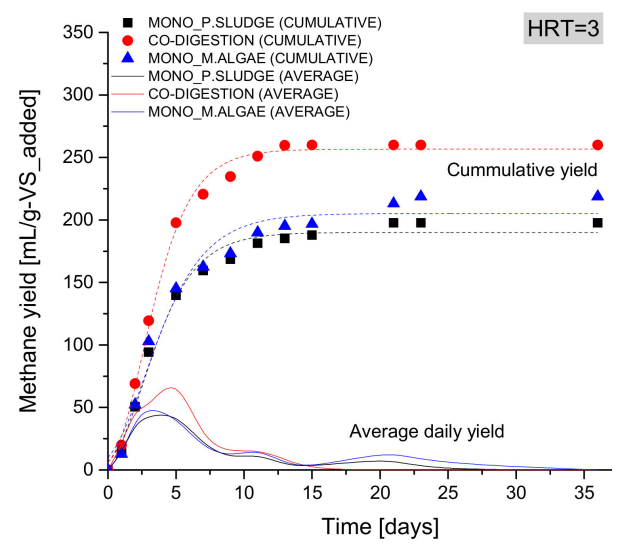

$€$

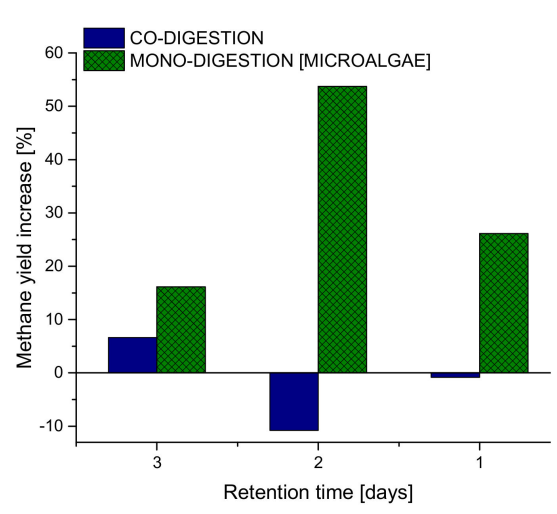

(b)

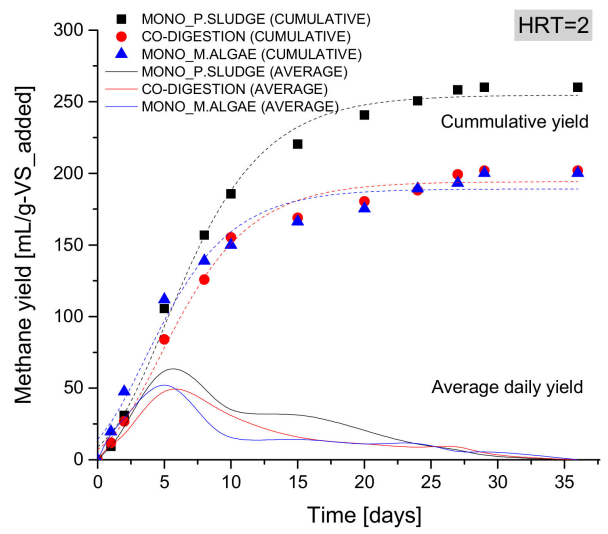

(d)

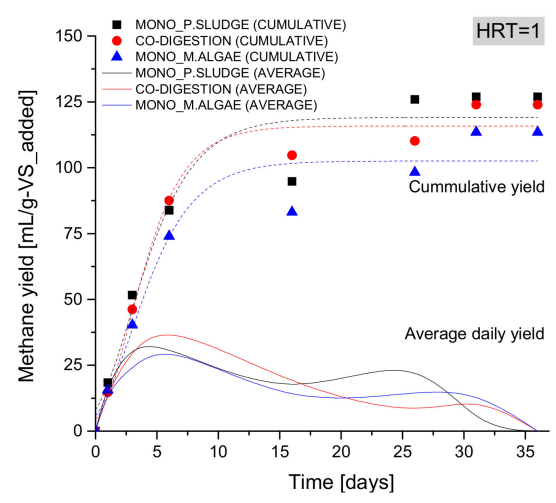

(e)

Figure 4. Methane yield at different HRTs after anaerobic biological pretreatment: (a) experimental maximum yield; (b) percentage increase in methane yield as compared to no pretreatment condition; (c-e) experimental vs. simulated values at different HRTs [Experimental condition: Mesophilic AD temperature $=35^{\circ} \mathrm{C}$, Sludge/algae ratio for co-digestion $=9, p H=7.1 \pm 0.2, I S R=2$, Working $A D$ volume $=150 \mathrm{~mL}]$. 
The results from the kinetic model parameters in Table 4 also show that co-digestion after anaerobic pretreatment enhanced methane yield and methane production rate by $9 \%\left(\mathrm{G}_{0}=256.7 \mathrm{~mL} / \mathrm{g}\right.$-VS_added $)$ and $46 \%\left(R_{\max }=30.7 \mathrm{~mL} / \mathrm{g}\right.$-VS_added/day), respectively. However, there was a significant lag period $(\lambda=0.63$ days) that might arise from the initially slower bacterial activity from the anaerobic microbes. A comparison between the aerobic and anaerobic pretreatments showed that maximum methane yield $\left(\mathrm{G}_{0}\right)$ was superior in aerobic pretreatment but the anaerobic process significantly improved methane production rates $\left(R_{\max }\right)$. A similar result has been reported previously [10]. This efficiency emanates mainly from the high performance of the anaerobic process in breaking down the biopolymers in microalgae because anaerobic microbes are capable of generating powerful cellulosome enzymes to effectively break down complex and recalcitrant biopolymers such as cellulose, hemicellulose, and pectin from microalgae and plant cell walls [12].

Table 4. Kinetic model parameters (after anaerobic pretreatment involved).

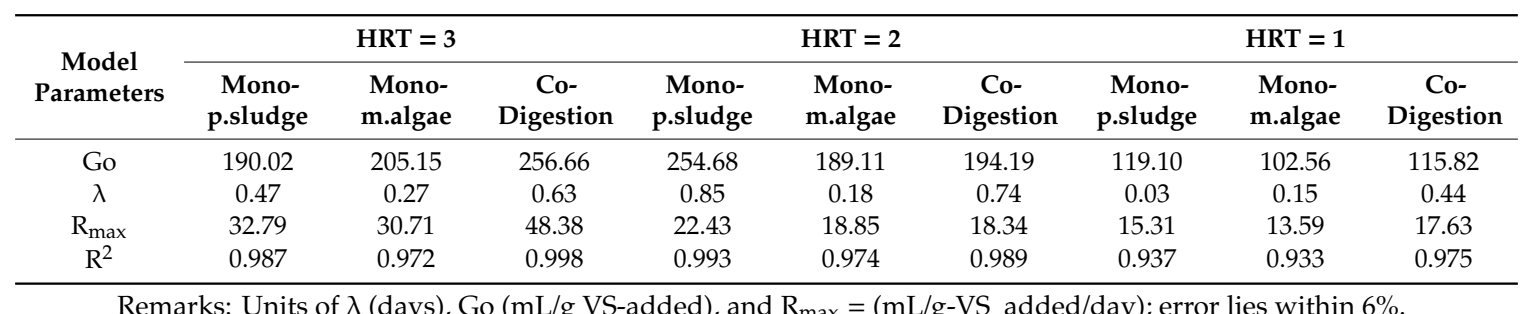

\subsubsection{Co-Digestion after $85^{\circ} \mathrm{C}$ Anaerobic Pretreatment}

This condition showed the highest performance for mono-microalgae digestion ( $242 \mathrm{~mL} / \mathrm{g}$-VS_added at an HRT of 3 days) and enhanced methane yield by more than $28 \%$ (see Figure 5a). The yield from co-digestion, however, surprisingly declined by $26 \%$ and $4 \%$ at an HRT of 3 days and an HRT of 2 days, respectively, while showing an 18\% increase at an HRT of 1 day (see Figure $5 \mathrm{~b}$ ). This indicated a lack of synergism under anaerobic conditions at higher temperatures, such that co-digestion adversely affected methane yield. At $85^{\circ} \mathrm{C}$ temperature, no microbes will survive, including nearly all the thermophile microbes and archaea, assuring very reduced biological activity during pretreatment-less archaeal abundance reduced the rate of hydrolysis and bio-solubilization of the polymers in the microalgae [31]. Moreover, applying $85^{\circ} \mathrm{C}$ temperature was not sufficient to achieve a desired thermal pretreatment effect [32]. As a result of this, neither the biological nor the thermal pretreatment was activated under $85^{\circ} \mathrm{C}$ conditions to enhance co-digestion performance. A similar reduction in performance after $65^{\circ} \mathrm{C}$ pretreatment has been reported $[10,33,34]$. The most severe methane reduction at an HRT of 3 days was attributed to the negative thermal effect being even worse when applied for a prolonged retention period. The yield enhancement at an HRT of 1 day might result from the partial existence of some microbial species at $85^{\circ} \mathrm{C}$ if a short retention time is applied. Additionally, the results from the kinetic study shown in Table 5 and Figure $5 \mathrm{c}-\mathrm{e}$ indicate that even though the lag period showed significant improvements, the methane production rate exhibited a declining trend. 


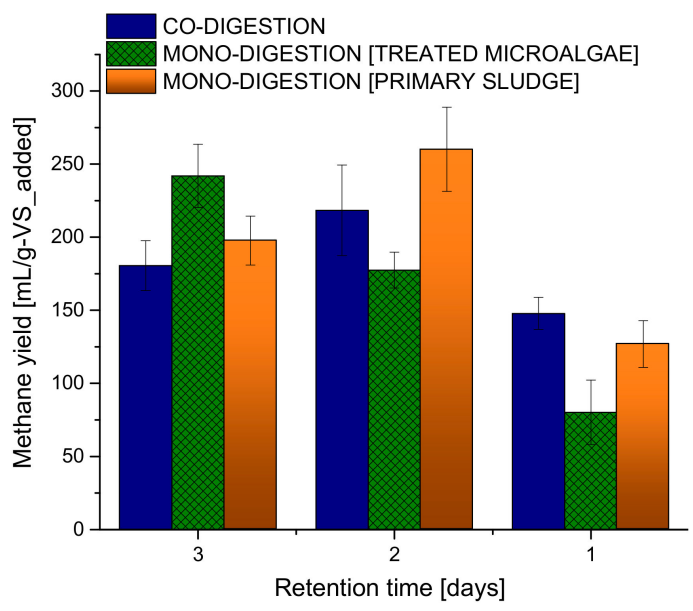

(a)

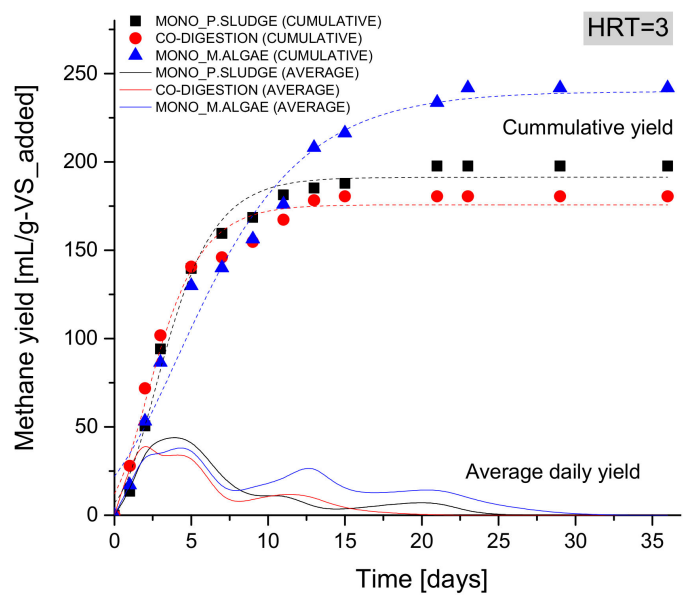

(c)

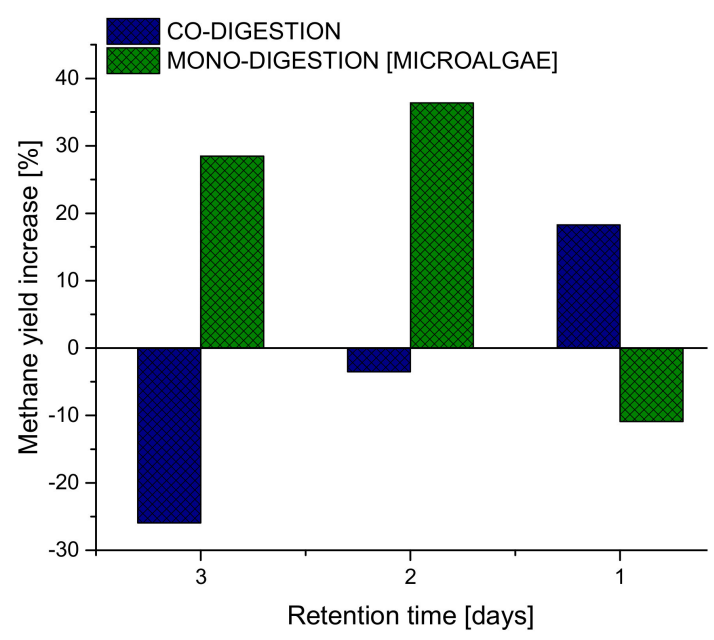

(b)

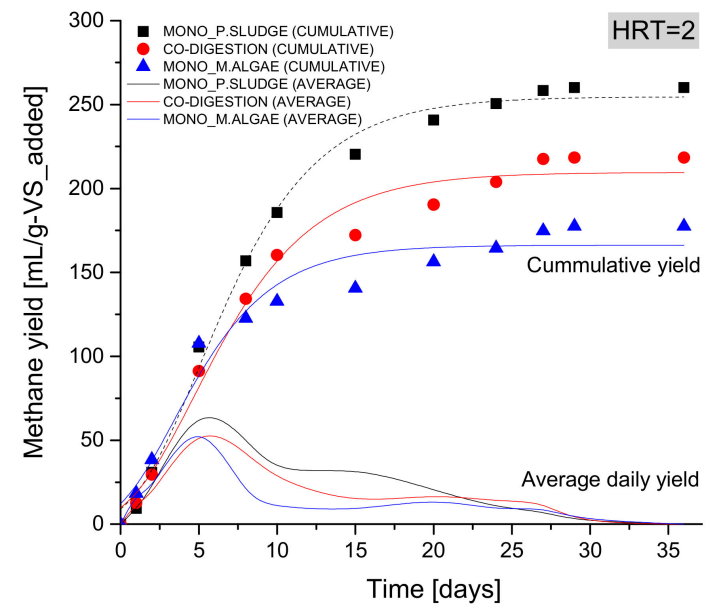

(d)

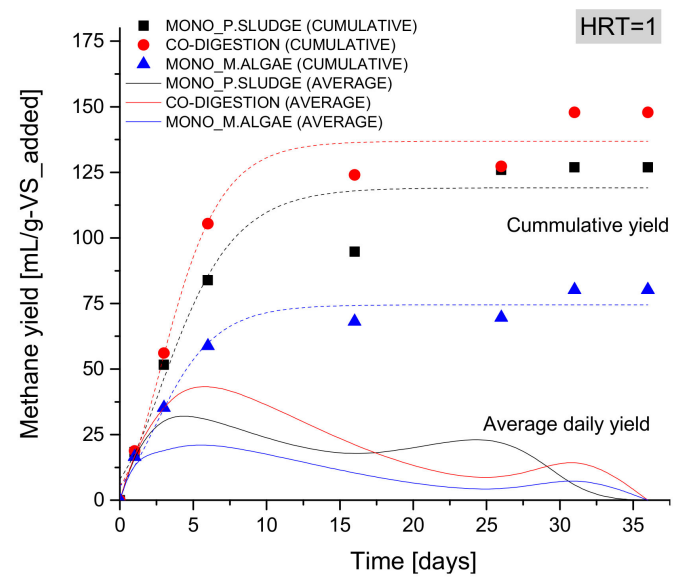

(e)

Figure 5. Methane yield at different HRTs after $85^{\circ} \mathrm{C}$ anaerobic biological pretreatment: (a) experimental maximum yield; (b) percentage increase in methane yield as compared to no pretreatment condition; (c-e) experimental vs. simulated values at different HRTs [Experimental condition: Mesophilic AD temperature $=35^{\circ} \mathrm{C}$, Sludge/algae ratio for co-digestion $=9, p H=7.1 \pm 0.2, I S R=2$, Working $A D$ volume $=150 \mathrm{~mL}]$. 
Table 5. Kinetic model parameters (after $85^{\circ} \mathrm{C}$ anaerobic pretreatment).

\begin{tabular}{|c|c|c|c|c|c|c|c|c|c|}
\hline \multirow{2}{*}{$\begin{array}{c}\text { Model } \\
\text { Parameters }\end{array}$} & \multicolumn{3}{|c|}{ HRT $=3$} & \multicolumn{3}{|c|}{ HRT $=2$} & \multicolumn{3}{|c|}{ HRT $=1$} \\
\hline & $\begin{array}{l}\text { Mono- } \\
\text { p.sludge }\end{array}$ & $\begin{array}{l}\text { Mono- } \\
\text { m.algae }\end{array}$ & $\begin{array}{c}\text { Co- } \\
\text { Digestion }\end{array}$ & $\begin{array}{l}\text { Mono- } \\
\text { p.sludge }\end{array}$ & $\begin{array}{l}\text { Mono- } \\
\text { m.algae }\end{array}$ & $\begin{array}{c}\text { Co- } \\
\text { Digestion }\end{array}$ & $\begin{array}{l}\text { Mono- } \\
\text { p.sludge }\end{array}$ & $\begin{array}{l}\text { Mono- } \\
\text { m.algae }\end{array}$ & $\begin{array}{c}\text { Co- } \\
\text { Digestion }\end{array}$ \\
\hline$\lambda$ & 0.44 & 0.60 & 0.03 & 0.85 & 0.15 & 0.50 & 0.03 & 0.07 & 0.40 \\
\hline$R_{\max }$ & 32.24 & 18.94 & 31.46 & 22.43 & 17.35 & 18.13 & 15.31 & 11.40 & 21.28 \\
\hline $\mathrm{R}^{2}$ & 0.987 & 0.973 & 0.977 & 0.994 & 0.96 & 0.983 & 0.9367 & 0.964 & 0.969 \\
\hline
\end{tabular}

Remarks: Units of $\lambda$ (days), Go (mL/g VS-added), and $R_{\max }=$ (mL/g-VS_added/day); error lies within 6\%.

\subsection{Performance Comparison with Previous Works}

The performance of this study was compared with some other previous works. The results indicated in Table 6, below, show that methane yield in a temperature-phased thermophilic bioreactor can be one of the most competitive pretreatment and methane production techniques. 
Table 6. Comparison between biomethanization tendency of this study and some other previous works.

\begin{tabular}{|c|c|c|c|c|c|}
\hline SN & Type of Process & Type of Substrate & Experimental Conditions & Methane Yield & Reference \\
\hline 1 & $\begin{array}{l}\text { Thermal pretreatment } \\
\text { and co-digestion }\end{array}$ & $\begin{array}{l}\text { Microalgae, primary } \\
\text { sludge and FOG }\end{array}$ & $\begin{array}{c}\text { Thermal pretreatment }\left(75^{\circ} \mathrm{C} \text { for } 10 \mathrm{~h}\right), \mathrm{BMP} \text { Temp }=35^{\circ} \mathrm{C} \\
\text { VS-based microalgae to sludge ratio }=50-50 \%\end{array}$ & $\begin{array}{l}237 \pm 1,298 \pm 12, \text { and } 334 \pm 1 \mathrm{~mL} \\
\mathrm{CH} 4 / \mathrm{gVS} \text { for FOG }=0 \%, \mathrm{FOG}=10 \% \\
\text { and FOG }=20 \% \text { resp. }\end{array}$ & [7] \\
\hline 2 & $\begin{array}{l}\text { Thermal pretreatment } \\
\text { and co-digestion }\end{array}$ & $\begin{array}{l}\text { Microalgae and } \\
\text { primary sludge }\end{array}$ & $\begin{array}{c}\text { Thermal pretreatment }\left(120^{\circ} \mathrm{C} \text { for } 40 \mathrm{~min}\right), \mathrm{BMP} \text { Temp }=35^{\circ} \mathrm{C} \text {, } \\
\text { Microalgae and sludge ratio }=\text { varying }\end{array}$ & $\begin{array}{c}261.7,282.8 \text { and } 293.4 \mathrm{~mL} \mathrm{CH}_{4} / \mathrm{COD} \\
\text { for ratio }=75 \% / 25 \%, 50 \% / 50 \% \text { and } \\
\qquad 25 \% / 75 \% \text { resp. }\end{array}$ & \multirow{2}{*}{ [6] } \\
\hline 3 & $\begin{array}{l}\text { Thermal pretreatment } \\
\text { and co-digestion }\end{array}$ & $\begin{array}{l}\text { Microalgae and } \\
\text { Secondary sludge }\end{array}$ & $\begin{array}{c}\text { Thermal pretreatment }\left(120^{\circ} \mathrm{C} \text { for } 40 \mathrm{~min}\right), \mathrm{BMP} \text { Temp }=35^{\circ} \mathrm{C}, \\
\text { Microalgae and secondary sludge ratio }=\text { varying }\end{array}$ & $\begin{array}{c}\sim 150,136 \text { and } 102 \mathrm{~mL} \mathrm{CH}_{4} / \mathrm{COD} \text { for } \\
\text { ratio }=75 \% / 25 \%, 50 \% / 50 \% \text { and } \\
25 \% / 75 \% \text { resp. }\end{array}$ & \\
\hline 4 & $\begin{array}{l}\text { Thermo-alkaline } \\
\text { pretreatment and } \\
\text { co-digestion }\end{array}$ & $\begin{array}{l}\text { Microalgal biomass } \\
\text { and wheat straw }\end{array}$ & $\begin{array}{c}\text { Thermo-alkaline pretreatment }\left(72^{\circ} \mathrm{C} \text { for } 24 \mathrm{~h}\right), \mathrm{HRT}=20 \text { days, } \\
\text { Total operation }=106 \text { days, OLR }=1.5 \mathrm{~g} \text { VS/L-day, BMP } \\
\text { Temp }=37 \pm 1{ }^{\circ} \mathrm{C} \text {, microalgae to straw ratio }(50-50 \%)\end{array}$ & $0.24 \mathrm{~L} \mathrm{CH}_{4} / \mathrm{g}$ vs. & [17] \\
\hline 5 & $\begin{array}{l}\text { Thermal pretreatment } \\
\text { and co-digestion }\end{array}$ & $\begin{array}{l}\text { Microalgae and } \\
\text { primary sludge }\end{array}$ & $\begin{array}{c}\text { Thermal pretreatment }\left(75^{\circ} \mathrm{C} \text { for } 10 \mathrm{~h}\right), \mathrm{HRT}=20 / 30 \text { days, } \\
\text { Microalgae/sludge ratio }=25 \% / 75 \%, \mathrm{BMP} \text { Temp }=37 \pm 1{ }^{\circ} \mathrm{C} \text {, } \\
\text { OLR }=1.17(\mathrm{~g} \mathrm{VS} / \mathrm{L} \cdot \text { day })\end{array}$ & $\left.0.46 \pm 0.27 \mathrm{~L} \mathrm{CH}_{4} / \mathrm{g} \mathrm{VS}\right)$ & [35] \\
\hline 6 & $\begin{array}{l}\text { Enzymatic pretreatment } \\
\text { and co-digestion }\end{array}$ & $\begin{array}{l}\text { algal residues and Pennisetum } \\
\text { hybrid energy grass }\end{array}$ & $\begin{array}{l}\text { Mixed enzyme (Cellulase, Xynalase, Pectinase) } \\
\text { algal to grass ratio }=1: 3 \text { (VS-based), BMP Temp }=35^{\circ} \mathrm{C}\end{array}$ & $207.35 \pm 15.66 \mathrm{mLCH}_{4} / \mathrm{gVS}$ & [36] \\
\hline 7 & $\begin{array}{l}\text { Alkaline pretreatment } \\
\text { and co-digestion }\end{array}$ & $\begin{array}{l}\text { Microalgae and mixed } \\
\text { primary secondary sludge }\end{array}$ & $\begin{array}{l}\text { Alkaline treatment }(0.1 \mathrm{~mol} / \mathrm{L} \mathrm{NaOH} \text { for } 12 \mathrm{~h}) \text {, Microalgae to } \\
\text { sludge ratio } 2: 1, \mathrm{BMP} \text { Temp }=35 \pm 1^{\circ} \mathrm{C} \text {, one month experiment }\end{array}$ & $298 \mathrm{mLCH}_{4} / \mathrm{gVS}$ & [37] \\
\hline 8 & $\begin{array}{l}\text { Temperature phased } \\
\text { Anaerobic co-digestion }\end{array}$ & Activated sludge & $\begin{array}{c}\text { Pretreatment HRT }=2 \text { days } \mathrm{pH}=7, \text { Temp }=\text { varying, } \mathrm{BMP} \\
\text { Temp }=37^{\circ} \mathrm{C}\end{array}$ & $\begin{array}{l}160 \mathrm{~mL} / \mathrm{gVS} \text { and } 300 \mathrm{~mL} / \mathrm{gVS} \text { for } \\
50^{\circ} \mathrm{C} \text { and } 65^{\circ} \mathrm{C} \text { resp. }\end{array}$ & [34] \\
\hline 9 & $\begin{array}{l}\text { Temperature phased } \\
\text { co-digestion }\end{array}$ & $\begin{array}{l}\text { Microalgae with } \\
\text { primary sludge }\end{array}$ & $\begin{array}{c}\text { Thermophilic Aerobic }(\mathrm{HRT}=2 \text { days }) \text { and anaerobic } \\
(\mathrm{HRT}=3 \text { days }) \text { pretreatment at } 55^{\circ} \mathrm{C} \text {, Sludge/algae ratio }=9 \mathcal{E} \\
\text { ISR }=2, \text { BMP Temp }=35^{\circ} \mathrm{C}\end{array}$ & $308 \mathrm{~mL} / \mathrm{g}-\mathrm{VS}$ and $260 \mathrm{~mL} / \mathrm{g}-\mathrm{VS}$ & This study \\
\hline 10 & Only co-digestion & $\begin{array}{l}\text { mixed microalgae } \\
\text { and food waste }\end{array}$ & $\begin{array}{c}\text { BMP Temp }=35^{\circ} \mathrm{C}, \text { microalgae to food waste ratio }=0.2: 0.8, \\
\text { reaction day }=40 \text { days }\end{array}$ & $639.8 \pm 1.3 \mathrm{~mL} / \mathrm{g}$ VS_added & [38] \\
\hline 11 & Only co-digestion & $\begin{array}{l}\text { Microalgae and } \\
\text { primary sludge }\end{array}$ & $\begin{array}{l}\text { AnMBR, SRT }=100 \text { days, } \mathrm{HRT}=30 \text { days, OLR }=0.5 \mathrm{gVS} / \mathrm{L} \mathrm{d} \\
\text { Sludge to microalgae ratio }=62 \%: 38 \%, \text { BMP Temp }=35^{\circ} \mathrm{C}\end{array}$ & $\begin{array}{l}228 \pm 3 \text { and } 241 \pm 18 \mathrm{mLCH}_{4} / \mathrm{gCOD} \\
\text { for Vulgaris and Scenedesmus resp. }\end{array}$ & {$[39,40]$} \\
\hline 12 & Only co-digestion & $\begin{array}{l}\text { Microalgae and } \\
\text { primary sludge }\end{array}$ & $\begin{array}{c}\text { Microalgae to sludge ratio }(25 \% / 75 \% \text { vs.-based }) \\
\text { HRT }=20 \text { days, BMP Temp }=37 \pm 1{ }^{\circ} \mathrm{C}, \text { OLR }=1.89 \pm 0.26 \mathrm{~kg} \\
\mathrm{VS} / \mathrm{m}^{3} \cdot \text { day }\end{array}$ & $0.33 \pm 0.05 \mathrm{~m}^{3} \mathrm{CH}_{4} / \mathrm{kg} \mathrm{VS}$ & [41] \\
\hline
\end{tabular}

Abbreviations used in the table: solids retention times (SRT), hydraulic retention times (HRT), Anaerobic Membrane Bioreactor (AnMBR), organic loading rate (OLR), ISR = inoculum-substrate ratio, $\mathrm{FOG}=$ fat, oil and grease, $\mathrm{BMP}$ Temp = biochemical methane potential test temperature. 


\subsection{Implications on the Circular Economy}

Our cities are investigating the possibilities of applying clean, renewable and economically viable natural technologies permitting extraction of valuable resources from highly polluted waste and transforming a wasteful linear economic model to a sustainable circular economy [42]. As part of this campaign, the anaerobic digestion process exhibits great potential to recycle energy, materials, water and nutrients with excellent economic viability. The process is especially attractive from the point of view of resource recovery using nature-based solutions [43]. This study clearly addressed the various multi-purpose possibilities in which once microalgae are grown to remove pollutants from a wastewater plant, they can be further incorporated back into the digestion process for sustainable methane production. After extracting energy, there is still a large potential for the liquid phase to be reclaimed for water reuse and the solid phase valorized for nutrient recovery by using only natural microorganisms as principal agents. These microbes possess enzymes that can selectively target a specific substrate existing in the algal body. So far, microalgae pretreatment has mainly been applied to physicochemical, thermal and mechanical techniques. However, with this study, one may conclude that microbial biotechnology (biological pretreatment) also possesses strong potential as a nature-based solution for enhancing the circular economy.

\section{Conclusions}

Increased synergistic effects of co-digestion resulting in up to $36 \%$ increase in methane yield were observed from the co-digestion of microalgae and primary sludge pretreated by thermophilic aerobic conditions at $55{ }^{\circ} \mathrm{C}$ and an HRT of 2 days. A maximum methane yield increase of only $8.3 \%$ was observed by anaerobic pretreatment at $55{ }^{\circ} \mathrm{C}$ and an HRT of 3 days. However, no synergistic effect was observed after pretreating and co-digesting the substrate with high-temperature $\left(85^{\circ} \mathrm{C}\right)$ anaerobic pretreatment. In fact, co-digestion reduced methane yield. Synergistic effects in co-digestion were observed without including any pretreatment. This work demonstrated conditions (high temperature; long HRT) of biological aerobic/anaerobic pretreatment in which co-digestion may negatively affect methane yield.

Author Contributions: Analyzing data and writing the original draft, M.M.D., data curation, methodology, J.S., conceptualization, conceiving and designing the experiment, H.M.J., project administration, resources, supervision, validation and manuscript editing, Y.M.K., M.M.D. and J.S. contributed equally to this paper. Both qualify as first author. All authors have read and agreed to the published version of the manuscript.

Funding: This research was supported by the Basic Science Research Program through the National Research Foundation of Korea (NRF) funded by the Ministry of Education (2017R1D1A1B03029456). This research was also supported by the Basic Science Research Program through the National Research Foundation of Korea (NRF) funded by the Ministry of Education (2020R1I1A3051671).

Conflicts of Interest: The authors declare no conflict of interest.

\section{References}

1. Ghaffari, Y.; Gupta, N.K.; Bae, J.; Kim, K.S. One-step fabrication of Fe2O3/Mn2O3 nanocomposite for rapid photodegradation of organic dyes at neutral pH. J. Mol. Liq. 2020, 113691. [CrossRef]

2. Bao, T.; Damtie, M.M.; Yu, Z.M.; Liu, Y.; Jin, J.; Wu, K.; Deng, C.X.; Wei, W.; Wei, X.L.; Ni, B.-J. Green synthesis of Fe3O4@carbon filter media for simultaneous phosphate recovery and nitrogen removal from domestic wastewater in biological aerated filters. ACS Sustain. Chem. Eng. 2019, 7, 16698-16709. [CrossRef]

3. Bao, T.; Yu, Z.M.; Damtie, M.M.; Wu, K.; Jin, J.; Zhang, Y.; Wei, X.L.; Frost, R.L. Use of autoclaved aerated concrete particles for simultaneous removal of nitrogen and phosphorus as filter media from domestic wastewater. Environ. Technol. 2019, 1-11. [CrossRef] [PubMed]

4. Ray, M.; Kumar, N.; Kumar, V.; Negi, S.; Banerjee, C. Microalgae: A way forward approach towards wastewater treatment and bio-fuel production. In Applied Microbiology and Bioengineering; Shukla, P., Ed.; Academic Press: London, UK, 2019; pp. 229-243, ISBN 9780128154076. 
5. Ward, A.J.; Lewis, D.M.; Green, F.B. Anaerobic digestion of algae biomass: A review. Algal Res. 2014, 5, 204-214. [CrossRef]

6. Mahdy, A.; Mendez, L.; Ballesteros, M.; González-Fernández, C. Algaculture integration in conventional wastewater treatment plants: Anaerobic digestion comparison of primary and secondary sludge with microalgae biomass. Bioresour. Technol. 2015, 184, 236-244. [CrossRef]

7. Solé-Bundó, M.; Garfí, M.; Ferrer, I. Pretreatment and co-digestion of microalgae, sludge and fat oil and grease (FOG) from microalgae-based wastewater treatment plants. Bioresour. Technol. 2020, 298, 122563. [CrossRef]

8. Wang, Q.; Prasad, R.; Higgins, B.T. Aerobic bacterial pretreatment to overcome algal growth inhibition on high-strength anaerobic digestates. Water Res. 2019, 162, 420-426. [CrossRef]

9. Bohutskyi, P.; Phan, D.; Kopachevsky, A.M.; Chow, S.; Bouwer, E.J.; Betenbaugh, M.J. Synergistic co-digestion of wastewater grown algae-bacteria polyculture biomass and cellulose to optimize carbon-to-nitrogen ratio and application of kinetic models to predict anaerobic digestion energy balance. Bioresour. Technol. 2018, 269, 210-220. [CrossRef]

10. Ge, H.; Jensen, P.D.; Batstone, D.J. Pre-treatment mechanisms during thermophilic-mesophilic temperature phased anaerobic digestion of primary sludge. Water Res. 2010, 44, 123-130. [CrossRef]

11. Atelge, M.R.; Atabani, A.E.; Banu, J.R.; Krisa, D.; Kaya, M.; Eskicioglu, C.; Kumar, G.; Lee, C.; Yildiz, Y.Ş.; Unalan, S.; et al. A critical review of pretreatment technologies to enhance anaerobic digestion and energy recovery. Fuel 2020, 270, 117494. [CrossRef]

12. Carrillo-Reyes, J.; Barragán-Trinidad, M.; Buitrón, G. Biological pretreatments of microalgal biomass for gaseous biofuel production and the potential use of rumen microorganisms: A review. Algal Res. 2016, 18, 341-351. [CrossRef]

13. Lv, W.; Schanbacher, F.L.; Yu, Z. Putting microbes to work in sequence: Recent advances in temperature-phased anaerobic digestion processes. Bioresour. Technol. 2010, 101, 9409-9414. [CrossRef] [PubMed]

14. Jang, H.M.; Cho, H.U.; Park, S.K.; Ha, J.H.; Park, J.M. Influence of thermophilic aerobic digestion as a sludge pre-treatment and solids retention time of mesophilic anaerobic digestion on the methane production, sludge digestion and microbial communities in a sequential digestion process. Water Res. 2014, 48, 1-14. [CrossRef]

15. Mshandete, A.; Björnsson, L.; Kivaisi, A.K.; Rubindamayugi, S.T.; Mattiasson, B. Enhancement of anaerobic batch digestion of sisal pulp waste by mesophilic aerobic pre-treatment. Water Res. 2005, 39, 1569-1575. [CrossRef]

16. Wang, M.; Sahu, A.K.; Rusten, B.; Park, C. Anaerobic co-digestion of microalgae Chlorella sp. and waste activated sludge. Bioresour. Technol. 2013, 142, 585-590. [CrossRef]

17. Solé-Bundó, M.; Eskicioglu, C.; Garfí, M.; Carrère, H.; Ferrer, I. Anaerobic co-digestion of microalgal biomass and wheat straw with and without thermo-alkaline pretreatment. Bioresour. Technol. 2017, 237, 89-98. [CrossRef]

18. Olsson, J.; Feng, X.M.; Ascue, J.; Gentili, F.G.; Shabiimam, M.A.; Nehrenheim, E.; Thorin, E. Co-digestion of cultivated microalgae and sewage sludge from municipal waste water treatment. Bioresour. Technol. 2014, 171, 203-210. [CrossRef]

19. Lee, J.; Jeon, J.H.; Shin, J.; Jang, H.M.; Kim, S.; Song, M.S.; Kim, Y.M. Quantitative and qualitative changes in antibiotic resistance genes after passing through treatment processes in municipal wastewater treatment plants. Sci. Total Environ. 2017, 605, 906-914. [CrossRef]

20. APHA/AWWA/WEF 2540 solids. In Standard Methods for the Examination of Water and Wastewater, 23rd ed.; American Public Health Association: Washington, DC, USA, 2018.

21. Filer, J.; Ding, H.H.; Chang, S. Biochemical methane potential (BMP) assay method for anaerobic digestion research. Water 2019, 11, 921. [CrossRef]

22. Li, P.; Li, W.; Sun, M.; Xu, X.; Zhang, B.; Sun, Y. Evaluation of biochemical methane potential and kinetics on the anaerobic digestion of vegetable crop residues. Energies 2019, 12, 26. [CrossRef]

23. Wang, M.; Lee, E.; Dilbeck, M.P.; Liebelt, M.; Zhang, Q.; Ergas, S.J. Thermal pretreatment of microalgae for biomethane production: Experimental studies, kinetics and energy analysis. J. Chem. Technol. Biotechnol. 2017, 92, 399-407. [CrossRef]

24. Damtie, M.M.; Choi, J.-S.; Shon, H.K. Fluoride Removal and Nitrogen Recovery from Wastewater by Membrane Distillation Process. Ph.D. Thesis, University of Science and Technology (UST), Daejeon, Korea, 2020.

25. Damtie, M.M.; Choi, J.-S. Modeling and application of direct contact membrane distillation for fluoride removal from aqueous solutions. Desalin. Water Treat. 2017, 97, 23-40. [CrossRef] 
26. Bao, T.; Damtie, M.M.; Hosseinzadeh, A.; Frost, R.L.; Yu, Z.M.; Jin, J.; Wu, K. Catalytic degradation of P-chlorophenol by muscovite-supported nano zero valent iron composite: Synthesis, characterization, and mechanism studies. Appl. Clay Sci. 2020, 195, 105735. [CrossRef]

27. Li, R.; Tan, W.; Zhao, X.; Dang, Q.; Song, Q.; Xi, B.; Zhang, X. Evaluation on the methane production potential of wood waste pretreated with $\mathrm{NaOH}$ and co-digested with pig manure. Catalysts 2019, 9, 539. [CrossRef]

28. Singh, B.; Bauddh, K.; Bux, F. (Eds.) Algae and environmental sustainability. In Developments in Applied Phycology; Springer: New Delhi, India, 2015; ISBN 9788132226390.

29. Mendez, L.; Mahdy, A.; Timmers, R.A.; Ballesteros, M.; González-Fernández, C. Enhancing methane production of Chlorella vulgaris via thermochemical pretreatments. Bioresour. Technol. 2013, 149, 136-141. [CrossRef] [PubMed]

30. Solé-Bundó, M.; Carrère, H.; Garfí, M.; Ferrer, I. Enhancement of microalgae anaerobic digestion by thermo-alkaline pretreatment with lime (CaO). Algal Res. 2017, 24, 199-206. [CrossRef]

31. Fuchs, A.; Lyautey, E.; Montuelle, B.; Casper, P. Effects of increasing temperatures on methane concentrations and methanogenesis during experimental incubation of sediments from oligotrophic and mesotrophic lakes. J. Geophys. Res. Biogeosci. 2016, 121, 1394-1406. [CrossRef]

32. Schwede, S.; Rehman, Z.-U.; Gerber, M.; Theiss, C.; Span, R. Effects of thermal pretreatment on anaerobic digestion of Nannochloropsis salina biomass. Bioresour. Technol. 2013, 143, 505-511. [CrossRef]

33. Bolzonella, D.; Cavinato, C.; Fatone, F.; Pavan, P.; Cecchi, F. High rate mesophilic, thermophilic, and temperature phased anaerobic digestion of waste activated sludge: A pilot scale study. Waste Manag. 2012, 32, 1196-1201. [CrossRef]

34. Ge, H.; Jensen, P.D.; Batstone, D.J. Increased temperature in the thermophilic stage in temperature phased anaerobic digestion (TPAD) improves degradability of waste activated sludge. J. Hazard. Mater. 2011, 187, 355-361. [CrossRef]

35. Solé-Bundó, M.; Salvadó, H.; Passos, F.; Garfí, M.; Ferrer, I. Strategies to optimize microalgae conversion to biogas: Co-digestion, pretreatment and hydraulic retention time. Molecules 2018, 23, 2096. [CrossRef] [PubMed]

36. Zhang, Y.; Kang, X.; Wang, Z.; Kong, X.; Li, L.; Sun, Y.; Zhu, S.; Feng, S.; Luo, X.; Lv, P. Enhancement of the energy yield from microalgae via enzymatic pretreatment and anaerobic co-digestion. Energy 2018, 164, 400-407. [CrossRef]

37. Du, X.; Tao, Y.; Liu, Y.; Li, H. Stimulating methane production from microalgae by alkaline pretreatment and co-digestion with sludge. Environ. Technol. 2020, 41, 1546-1553. [CrossRef] [PubMed]

38. Zhen, G.; Lu, X.; Kobayashi, T.; Kumar, G.; Xu, K. Anaerobic co-digestion on improving methane production from mixed microalgae (Scenedesmus sp., Chlorella sp.) and food waste: Kinetic modeling and synergistic impact evaluation. Chem. Eng. J. 2016, 299, 332-341. [CrossRef]

39. Zamorano-López, N.; Borrás, L.; Seco, A.; Aguado, D. Unveiling microbial structures during raw microalgae digestion and co-digestion with primary sludge to produce biogas using semi-continuous AnMBR systems. Sci. Total Environ. 2020, 699, 134365. [CrossRef]

40. Serna-García, R.; Zamorano-López, N.; Seco, A.; Bouzas, A. Co-digestion of harvested microalgae and primary sludge in a mesophilic anaerobic membrane bioreactor (AnMBR): Methane potential and microbial diversity. Bioresour. Technol. 2020, 298, 122521. [CrossRef]

41. Solé-Bundó, M.; Garfí, M.; Matamoros, V.; Ferrer, I. Co-digestion of microalgae and primary sludge: Effect on biogas production and microcontaminants removal. Sci. Total Environ. 2019, 660, 974-981. [CrossRef]

42. Cuadros-Blázquez, F.; González-González, A.; Sánchez-Sánchez, C.; Díaz-Rodríguez, V.; Cuadros-Salcedo, F. Waste valorization as an example of circular economy in extremadura (Spain). J. Clean. Prod. 2018, 181, 136-144. [CrossRef]

43. Kisser, J.; Wirth, M.; de Gusseme, B.; van Eekert, M.; Zeeman, G.; Schoenborn, A.; Vinnerås, B.; Finger, D.C.; Kolbl-Repinc, S.; Bulc, T.G.; et al. A review of nature-based solutions for resource recovery in cities. Blue Green Syst. 2020, 2, 138-172. [CrossRef]

(C) 2020 by the authors. Licensee MDPI, Basel, Switzerland. This article is an open access article distributed under the terms and conditions of the Creative Commons Attribution (CC BY) license (http://creativecommons.org/licenses/by/4.0/). 